\title{
IMPLEMENTASI MATA PELAJARAN PENDIDIKAN AGAMA ISLAM SEBAGAI DASAR MENCIPTAKAN KEDISIPLINAN SISWA DI SMA AL- FURQON DRIYOREJO GRESIK
}

\section{Muhammad Refa Mashuri}

Universitas Hasyim Asy'ari Tebuireng, Jombang, Indonesia

Email: refamashuri020398@gmail.com

\begin{tabular}{l} 
INFO ARTIKEL \\
\hline Diterima \\
5 April 2021 \\
Direvisi \\
10 April 2021 \\
Disetujui \\
15 April 2021 \\
\hline
\end{tabular}

Keywords:

islam; religion; economy; generation;

implementation; santri

\begin{abstract}
Islam has a very good civilization in terms of economy and ownership and knowledge and do not forget power and so on. This does not rule out the possibility that Islam was once very fast and globalized. But in the last few years or decades Islam has become the biggest religion and audience. Because many future generations of Islam are neglected by the comfort of comfort. Therefore, the understanding of discipline is wanted to change the set of Muslims that in the past our ancestors were strong and tough people who controlled almost the entire earth. There is no kingdom or religion whatsoever like this. The implementation of Islamic religious education subjects as the basis for creating student discipline at SMA Al-Furqon Driyorejo Gresik is a very important foundation in the development of santri civilization.The method in this research is qualitative method. The purpose of the implementation of Islamic religious education on the basis of the dream of students at Al-Furqon High School can be in a favorite college with a scholarship with religious insight.
\end{abstract}

\section{ABSTRAK}

Islam memiliki peradaban yang sangat baik dari hal ekonomi dan kepemimpinan, keilmuan dan kekuasaan. Hal ini menunjukan bahwa peradaban islam pada asa dahulu sangat pesat. Tetapi beberapa tahun terakhir ini Islam menjadi agama terbesar dan penonton. Karena generasi penerus Islam yang terkena penyakit cinta dunia yaitu sikap mental yang mendahulukan dunia dibanding akhirat. Itu sederhananya. Dunia menjadi pertimbangan utama dalam ukuran kebahagiaan. Maka itu pengenalan kedisiplinan diinginkan untuk mengubah mindset orang Islam bahwa dahulu nenek moyang kita orang yang kuat dan tangguh yang menguasai hampir seluruh bumi. Implementasi mata pelajaran pendidikan agama Islam

\begin{tabular}{ll}
\hline How to cite: & Mashuri, Muhammad Refa (2021) Implementasi Mata Pelajaran Pendidikan Agama Islam Sebagai \\
& Dasar Menciptakan Kedisiplinan Siswa Di Sma Al-Furqon Driyorejo Gresik. Jurnal Syntax \\
& Admiration 2(4). https://doi.org/10.46799/jsa.v2i4.211 \\
E-ISSN: & 2722-5356 \\
Published by: & Ridwan Institute
\end{tabular}


sebagai dasar menciptakan kedisiplinan siswa di SMA Al-Furqon Driyorejo Gresik menjadi pondasi yang sangat penting dalam pembangunan peradaban santri. Metode dalam menulis penelitian ini adalah metode pendekatan kualitatif. Tujuan pelaksanaan implementasi pendidikan agama Islam sebagai dasar menciptakan kedisiplinan siswa di SMA Al-Furqon adalah dapat diterima di perguruan tinggi favorit dengan beasiswa yang berwawasan agama.

\section{Pendahuluan}

Perkembangan globalisasi menjadi sebuah keniscayaan yang tidak bisa dihindari, perkembangan tersebut memberi pengaruh besar dalam kehidupan remaja. Tantangan terberat dalam globalisasi adalah turunnya standar moralitas, agama dan kebudayaan pada kehidupan remaja. Hal ini dikarenakan para siswa sudah mengalami masa pubertas sehingga mereka mencoba mencari jati diri dan pengalaman dalam kehidupan sehingga terkadang mereka melakukan tindakan yang tidak sesuai dengan norma agama, hal ini menjadi perhatian serius bagi guru pendidik terutama guru agama (Machrus, 2011).

Islam memiliki peradaban yang sangat baik dari hal ekonomi dan kepemimpinan dan keilmuan serta tidak lupa kekuasaan Hal ini tidak menutup kemungkinan Islam yang dahulu sangat pesat dan mendunia. Tetapi beberapa tahun terakhir ini Islam menjadi agama terbesar dan penonton, karena generasi penerus Islam banyak yang terleha-leha dengan kemapanan selain itu generasi islam terjangkit virus Hubudd dunya yakni cinta dunia yaitu sikap mental yang mendahulukan dunia dibanding akhirat. Itu sederhananya (Maarif, 2019). Dunia menjadi pertimbangan utama dalam ukuran kebahagiaan. Maka itu pengenalan kedisiplinan diinginkan untuk mengubah mindset orang Islam bahwa dahulu nenek moyang kita orang yang kuat dan tangguh yang menguasai hampir seluruh bumi. Tidak ada kerajaan atau pun agama apa pun yang seperti ini (Pulungan, 2017).

Masalah di atas tentang agama, moral, dan budaya semuanya mencakup permasalahan tentang ilmu disiplin Sekolah Menengah Atas (SMA) Al-Furqon Driyorejo Gresik yang dipimpin oleh Bapak Suryanto S.PdI dan dengan bantuan tenaga pendidik yang kompeten membuat salah satu implementasi yaitu pendidikan agama Islam sebagai dasar menciptakan kedisiplinan siswa khusus yang akan membuat cinta dalam pembelajaran, yang mana implementasi tersebut tidak dimiliki oleh sekolah atau madrasah lain khususnya di sekitar Driyorejo. Adanya implementasi tersebut juga tidak lepas dari kerjasama pihak sekolah dan pondok pesantren yang berjalan dengan baik (Ekowanti \& Casmiwati, 2014). Implementasi tersebut baru berjalan selama 2 tahun yaitu mulai pelajaran 2018 .

Program merupakan rangkaian kegiatan yang dilakukan tetapi berkesinambungan. Pelaksanaan program selalu terjadi dalam sebuah organisasi yang harus dilibatkan sekelompok orang (Ahmad Susanto, 2018). Seperti halnya implementasi pendidikan agama Islam sebagai dasar menciptakan kedisiplinan siswa yang berdampak akan 
membuat cinta belajar siswa yang dibentuk di SMA Al-Furqon Driyorejo Gresik tersebut yang melibatkan banyak pihak yaitu pihak sekolah, pondok pesantren, guru PAI serta orang tua siswa (Syukri, 2015).

Tujuan pelaksanaan implementasi pendidikan agama Islam sebagai dasar menciptakan kedisiplinan siswa di SMA Al-Furqon adalah dapat diterima di perguruan tinggi favorit dengan beasiswa yang berwawasan agama dan berdasarkan wawancara pada 12 Desember 2019 dengan Bapak Suryanto S.Pd selaku kepala sekolah bahwa dibentuknya implementasi pendidikan agama Islam sebagai dasar menciptakan kedisiplinan siswa. Untuk melestarikan dan memelihara manusia yang ahlul ilmi yang khususnya generasi Islam yang semakin punah khususnya di pendidikan formal dan juga menjadikan umat Islam yang disiplin yang tinggi (Rahmat, 2019).

\section{Metode Penelitian}

Metode dalam menulis penelitian ini adalah metode pendekatan kualitatif. Penelitian kualitatif ditujukan untuk mendeskripsikan dan menganalisis fenomena, peristiwa, aktivitas sosial individu atau kelompok (Ghony \& Almanshur, 2012). Peneliti berupaya mendeskripsikan fenomena problematika kedisiplinan siswa di SMA AlFurqon.

Instrumen utama dalam penelitian kualitatif adalah peneliti sendiri. Namun, selanjutnya setelah fokus penelitian menjadi jelas, maka akan dikembangkan instrumen penelitian sederhana, yang diharapkan dapat melengkapi data dan membandingkan dengan data yang telah ditemukan melalui observasi dan wawancara sedangkan yang melakukan validasi adalah peneliti sendiri (Winarni, 2021). Penelitian ini dilakukan di SMA Al-Furqon berlokasi di jalan KH. Abdurrohim No. 01 Desa Wedoroanom RT 12, RW 04 Kecamatan Driyorejo Kabupaten Gresik Jawa Timur.

\section{Hasil dan Pembahasan}

1. Gambaran Setting Lokasi Penelitian

SMA Al-Furqon Driyorejo Gresik Pondok Pesantren Al-Furqon, berlokasi di Desa Wedoroanom Driyorejo Gresik, mempunyai nilai historis yang amat panjang karena keberadaan pondok pesantren ini tidak lepas perjuangan para perintis yang dipegang oleh beliau Bapak Kyai Mashuri Abdurrohim beliau bukan keturunan ningrat atau keturunan Kyai tetapi beliau adalah putra keempat dari tujuh bersaudara yang lahir dari seorang ayah yang bernama Abdurrohim dan Ibu Nyai Halimah yang kehidupan sehari-harinya sebagai petani (Sam, 2019).

Sejak tahun 1993, berawal dari keprihatinan beliau tentang kondisi pendidikan masyarakat Wedoroanom yang berada di garis bawah. Hal ini terindikasi oleh banyaknya anak-anak usia sekolah yang putus sekolah karena berbagai macam faktor penyebabnya. Seperti alasan ekonomi dan masih rendahnya pemahaman tentang pentingnya pendidikan serta minimnya sarana pendidikan yang mampu mengentaskan generasi anak bangsa. Masyarakat yang pada umumnya petani dan 
pedagang keliling beranggapan bahwa pendidikan tinggi pun percuma karena pada akhirnya nasibnya akan sama dengan orang tuanya yaitu menjadi petani yang bekerja setiap hari ke sawah atau kebun. Oleh karena itu, setelah melalui proses yang lama dan diawali dengan pendidikan non formal yaitu pengajian dan belajar bersama di musala yang terbuat dari bambu (gedek), anak-anak melakukan kegiatan rutin yang diasuh langsung beliau Kakanda Kyai Mashuri Abdurrohim yaitu Kyai Bashori Affandi Abdurohim dengan jumlah santri yang sedikit yaitu hanya 10 orang. Kemudian dengan semangat dan kegigihan beliau Kyai Mashuri Abdurrohim yang pada waktu itu masih berumur 24 tahun dan belum berkeluarga memutuskan untuk mengontrak sebuah rumah untuk dijadikan asrama dan sekaligus berfungsi sebagai kantor, tepatnya berada di Perumahan Taman Indah Menanggal Surabaya sebelah timur Masjid Al-Akbar Surabaya. Selama proses perencanaan pendirian yayasan, lebih dulu mendirikan lembaga sosial panti asuhan yang diberi nama "Insan Kamil" untuk menampung anak-anak yang belajar mengaji. Kegiatan pengajian dilaksanakan di aula atau musala Panti Asuhan Insan Kamil yang sangat sederhana sekali. Setelah beberapa tahun kemudian Kyai Mashuri beserta para perintis, mereka adalah Kyai Mashuri Abdurrohim, KH. Mas Bagus Rizqi, Khoirur Rozi dan para tokoh masyarakat sekitar lainya berdiskusi untuk mendirikan sebuah yayasan yang menyelenggarakan pendidikan formal kurang lebih 2 tahun lamanya mengontrak. Dengan izin Allah SWT dan dibantu oleh beberapa orang penyantun dan donatur yang ikut berpartisipasi mendirikan sebuah yayasan pondok pesantren yang diberi nama "Al-Furqon". Dalam hal ini peran dan sumbangsih yang tak terhingga dari beliau Direktur PT. Adhi Karya Surabaya Tbk. yaitu Bapak H. Sayoeti Soekamdi, MM. Memberikan bantuan baik berupa morel maupun harta sehingga terwujud bangunan dua lantai di atas tanah wakaf kurang lebih 2000 meter bahkan hingga sekarang. Adapun lembaga pendidikan formal yang pertama didirikan adalah Sekolah Menengah Atas (SMA) Al-Furqon tepatnya pada tahun 1995. Adapun santri angkatan pertama pada saat itu berjumlah 21 santri. Mereka berasal dari berbagai daerah wilayah Kabupaten Gresik bahkan ada dari luar Jawa. Proses perjalanan angkatan pertama ini hanya tersisa 11 santri yang mampu menyelesaikan pendidikannya hingga lulus.

Proses perkembangan Yayasan Pondok Pesantren Al-Furqon yang berdiri di tengah lingkungan masyarakat yang secara umum mengikuti paham Ahlussunnah Wal Jamaah Nahdlatul Ulama merasa agak aneh dengan nama yayasan itu yaitu "AlFurqon" yang identik dengan nama paham Muhammadiyah sehingga masyarakat yang merasa tidak senang dengan kehadiran lembaga ini mengecapnya dengan lembaga yang beraliran Muhammadiyah. Padahal sesungguhnya nama tersebut hanyalah sebuah nama yang pada pelaksanaan semua kegiatan yang ada di pondok pesantren ini beraliran Ahlusunah Waljama'ah atau menganut paham Nahdlatul Ulama. Proses kegiatan belajar mengajar di pondok pesantren ini menggunakan integrated kurikulum yaitu memadukan antara pendidikan umum dan agama yang bertujuan untuk menciptakan generasi bangsa yang handal baik dalam bidang umum 
maupun agama. Perjalanan perkembangan yayasan pondok pesantren ini berangsurangsur mendapatkan kepercayaan dari masyarakat, hal ini terbukti dengan adanya penambahan dari segi kuantitas atau jumlah santri yang masuk yaitu pada angkatan kedua berjumlah 40 santri dan angkatan ketiga berjumlah 37 santri dan alhamdulilah angkatan yang lulus sekarang yang ke 22 angkatan. Walaupun dalam proses perjalanannya ada yang sampai selesai bahkan ada pula yang memutuskan untuk berhenti sekolah ataupun mutasi, tutur Kyai Mashuri Abdurrohim.

2. Terbentuknya Kedisiplinan, Proses dan Daya Dukungnya tentang Disiplin Siswa di SMA Al-Furqon

Gambaran dasar tentang kedisiplinan siswa yaitu implementasi sistem formal dalam kegiatan belajar mengajar diwujudkan dalam bentuk pembelajaran dengan sistem konvensional atau metode ceramah, metode karya wisata dan role playing/berbagi peran.

a. Sistem konvensional atau ceramah

Diselengarakan satu minggu dua kali dalam satu pekan yang pertama siswasiswi berkumpul semua dari kelas 1 sampai 3 di Musala sesudah salat duha mulai pukul 07.00-08.00 WIB, yang kedua ketika siswa masuk pada mata pelajaran PAI dengan semuanya menggunakan kurikulum (K13) dan perpaduan kurikulum pesantren (Moleong, 2019).

b. Metode karya wisata

Diselenggarakan satu tahun dua kali ketika semester satu dan semester dua dengan memanfaatkan tempat-tempat yang memiliki sumber pengetahuan bagi siswa. Untuk mengajari dan menyelami sejarah Islam dengan pendampingan guru mapel PAI dan juru sejarah atau juru kunci tempat tersebut. Salah satunya mengunjungi situs makam para Walisongo, aulia Allah SWT dan para pemimpin Islam (Nasution, 2013).

Hal ini sesuai dengan apa yang dikatakan oleh Bapak Suherman M.Pd selaku Waka kurikulum SMA Al-Furqon, Driyorejo Gresik. Beliau mengatakan bahwa mengunjungi situs makam para walisongo, aulia Allah SWT dan para pemimpin Islam sambil memanjatkan doa dan dzikir sekaligus menggali Sejarah sudah bagus. Dibuktikan dalam siswa baru yang awalnya malas akan belajar dan tidak disiplin, sesudah pulang dari karya wisata langsung tidak mau terlambat dan sangat serius untuk belajar karena kamu akan mengetahui dunia dengan membaca dan belajar dengan disiplin ilmu karena nenek moyang kita Islam khususnya hampir menguasai dunia dengan disiplin ilmu yang sangat tinggi (Mardan \& Halim, 2011). Tetapi kita butuh evaluasi yang banyak karena kita sekolah yang berada di sekeliling sekolah yang maju apa lagi kita dekat dengan kota Surabaya yang arus modernisasi dalam bidang apapun khusus dunia pendidikan yang saling menjauh antara sekolah negeri dan swasta yang berbasis pondok maupun tidak (Setianingsih, 2017). Saya yakin kedepannya siswa jika tahu bahwa nenek moyang kita dahulu hampir menguasai dunia dengan disiplin ilmu yang sangat tinggi maka akan memacu siswa untuk selalu menggali dengan disiplin ilmu 
dengan membuat pacuhan kita pasti bisa, asal kita belajar dengan disiplin ilmu yang tinggi.

Kurikulum ini disusun secara mandiri oleh SMA dan Pesantren Al-Furqon dengan fokus pada pencapaian pelajaran target KKM yang dengan nilai yang sangat memuaskan bukan hanya disiplin saja, siswa juga memahami dan mengetahui sejarah yang sangat luas sesuai dengan perkataan bapak presiden kita yang pertama yang biasa kita kenal dengan bapak proklamasi atau Soekarno 'Jasmerah' (Jangan Pernah Melupakan Sejarah).

Adapun kebijakan kurikulum SMA Al-Furqon secara umum adalah sebagai berikut:

1) Landasan penyusunan kurikulum:

a) PAI adalah mapel istimewa

b) Materi penunjang diantaranya pemutaran film sejarah, karya wisata sejarah dan drama sejarah

c) Target sekolah disiplin adalah paling utama

d) Nilai siswa tidak boleh di bawah KKM yang sudah ada, jika ada maka ada pembimbingan secara khusus

Untuk menjamin kedisiplinan maka siswa tidak boleh di bawah nilai KKM dan tidak ada pelanggaran kedisiplinan dan rasa cinta keislaman dan kenegaraan yang tinggi.

Hal serupa juga disampaikan oleh salah satu siswa kelas IPS yang telah peneliti wawancarai, yang bernama Andi Fajar ia mengemukakan

"Mendengarkan penjelasan Bapak dan Ibu guru dapat menambah wawasan, dengan mengikuti pelajaran dan paparan guru dengan rajin dan disiplin bersama guru Sejarah Kebudayaan Islam. Sehingga saya tergugah semangat dalam mencari ilmu dan memahaminya dengan rasa cinta. Fajar mejelskan awalnya dia adalah siswa yang sangat malas ketika di SMP boro-boro saya ikut lomba masuk dalam sepuluh besar siswa terbaik saja tidak pernah. Sehabis saya masuk di SMA Al-Furqon saya termotivasi untuk selalu disiplin ilmu dan alhamdulillah saya masuk dalam sepuluh besar, sehingga mengikuti dan mewakili berbagai lomba yang diadakan berbagai lembaga dan madrasah yang ada di Gresik maupun di luar Gresik. Meskipun ada beberapa lomba yang tidak mendapatkan juara. Tetapi saya tidak pernah menyerah karena saya juga mendapatkan yang paling berharga yaitu pengalaman, disisi lain bisa mendapatkan ilmu dan mempererat silaturahmi". Dari penjelasan salah satu siswa tersebut bisa dipahami bahwa disiplin dalam belajar itu sangat penting dan yang utama adalah motivasi yang sangat kuat yang menambah semangat untuk selalu belajar.

Selain itu, kepala sekolah SMA Al-Furqon Bapak Suryanto M.Pd dengan hasil wawancara dengan guru Pendidikan Agama Islam Bapak Hanapi Ashar S.Pd.I pada hari Kamis tanggal 28 Mei 2020 pukul 08.00 WIB berpendapat bahwa semua kegiatan dan pembelajaran di SMA Al-Furqon ini sangat penting. Bukan hanya pembelajaran yang ada di dalam kelas saja, memang hal ini dimaksudkan agar para 
siswa, guru dan seluruh warga SMA Al-Furqon mendukung dan memantapkan kepribadian siswa untuk mewujudkan sekolah sebagai lingkungan pendidikan sehingga dari pengaruh negatif dan bertentangan dengan tujuan sekolah serta bersama-sama mewujudkan siswa agar menjadi warga yang berakhlak, berwawasan luas, tidak melupakan sejarah dan tak lupa disiplin dalam segala aspek kehidupan baik kelak jika sudah lulus. Menjadikan siswa-siswa agar rajin dan disiplin untuk mengikuti pembelajaran perlu adanya pembiasaan, seperti datang tidak tepat waktu ada hukuman. Alfa beberapa kali akan dipanggil, jadi hukuman sesuai dengan apa yang diperbuat, hukuman tersebut agar siswa jera dan tidak mengulanginya kembali.

Dari ketiga pendapat diatas, sudah jelas bahwa kedisiplinan sangat penting bagi siswa itu sendiri, guru serta warga yang ada di SMA Al-Furqon Driyorejo Gresik karena adanya pencerahan dan motivasi serta tak lupa sejarah Islam pernah jaya pada masa lalu siswa mendapatkan wawasan lebih luas serta pengalaman yang didapat pada waktu sekolah di SMA sehingga bisa meningkatkan prestasi siswa dan juga perlu penyesuain agar siswa SMA Al-Furqon lebih disiplin dan semangat.

3. Peran Pendidikan Agama Islam dalam Meningkatkan Kedisiplinan

Seperti yang sudah dijelaskan sebelumnya mengenai Pendidikan Agama Islam dalam meningkatkan kedisiplinan siswa. Perlu diketahui bahwa outputnya dapat meningkatkan prestasi belajar siswa di SMA Al-Furqon Driyorejo Gresik ini khususnya kelas satu IPS, karena peneliti melakukan observasi dalam pengumpulan data penelitian ini.

Hasil dari wawancara dengan kepala sekolah SMA Al-Furqon Bapak Suryanto M.Pd menyampaikan bahwa prestasi adalah suatu hasil setelah melakukan suatu kegiatan dalam proses belajar-mengajar. Peran guru Pendidikan Agama Islam dalam melakukan tersebut dengan disiplin membuahkan hasil sehingga dalam mengikuti berbagai perlombaan di berbagai daerah walau beberapa perlombaan ada yang tidak membawa juara tetapi prinsip yang dibawa oleh siswa adalah pengalaman yang dicari sehingga jika mendapatkan juara itu sebuah bonus dalam mengikuti perlombaan. Dengan usaha atau bekal percaya diri dan semangat siswa yang giat mengikuti pembelajaran dan mentaati peraturan. Dengan mengikuti bimbingan dan monitoring dari guru mata pelajaran pendidikan agama Islam ini siswa juga butuh pembiasaan dengan peraturan dan kebiasaan yang ada. Sehingga pembiasaan tersebut siswa akan terbiasa disiplin, tepat waktu dan akan menghasilkan suatu hasil karena mengikutinya.

Guru Pendidikan Agama Islam SMA Al-Furqon Driyorejo Gresik Bapak Hanip Ashar S.Pd.I juga menambahkan

"Meneladani dan mempelajari akhlak ini sangat penting untuk siswa dan sekolah. Dengan pemahaman ini siswa bisa membawa nama baik almamater sekolah. Sehingga siswa-siswi bisa meningkatkan prestasi karena dasar penunjang di lembaga kami adalah hasil dan buah kegiatan ini”.

Dalam perannya pendidikan agama Islam dalam meningkatkan kedisiplinan belajar siswa di SMA Al-Furqon Driyorejo Gresik ini. Bapak Waka kurikulum juga 
menambahkan bahwa "Dengan pendisiplinan siswa melalui pembelajaran Pendidikan Agama Islam sehingga siswa dapat disiplin dalam belajar sehingga memperluas pengetahuan berbagai mata pelajaran sehingga dapat meningkatkan disiplin belajar di SMA Al-Furqon lewat program ini siswa dapat lebih disiplin belajar pelajaran yang lain dan berdampak baik pada kedisiplinan belajar siswa di dalam maupun di luar ruangan kelas".

Adapun pendapat dari siswa kelas XI IPS Febri Lestari "Saya mengikuti pembelajaran dan binaan di SMA Al-Furqon ini dengan istikamah. Saya mengikuti olimpiade cerdas cermat sejarah karena saya suka dengan pelajaran PAI khususnya mengenai bab tentang sejarah. Dengan begitu saya bisa mengikuti lomba cerdas cermat mewakili sekolah meskipun tidak membawa piala tetapi saya bisa unggul atau mendapat peringkat 1 dari kelas X. Jadi memang membuahkan hasil ketika mengikuti pembelajaran dan pembinaan di sekolah.

4. Faktor Penghambat dan Pendukung Pendidikan Agama Islam dalam Meningkatkan Kedisiplinan Siswa

Peneliti melakukan observasi adanya faktor penghambat dan pendukung pendidikan agama Islam dalam meningkatkan kedisiplinan siswa di SMA Al-Furqon. Hasil wawancara dengan Waka kurikulum Bapak Suherman M.Pd menyampaikan "Untuk meningkatkan kedisiplinan siswa dengan mengikuti arahan dan binaan dan pembelajaran ini juga ada faktor penghambat dan pendukungnya. Faktor penghambatnya ada beberapa sarana prasarana yang kurang lengkap sehingga berpengaruhnya tidak baik untuk pelaksanaan binaan dan pembelajaran. Seperti film dokumenter tentang Imam Ghozali ataupun film dokumenter Hadratus Syekh Hasyim Asy'ari ketika masa mondok sehingga menjadikan beliau menjadi orang yang sangat luas dalam berkhazanah ilmu pengetahuan tetapi cukup disayangkan belum pembuatannya. Karena kami mencari film yang berkualitas dan mengandung semangat belajar sekaligus kedisiplinan ilmu dan kedisiplinan di segala aspek, saya harap baik film dokumenter sebuah pembelajaran inti sari manusia sebagai orang yang harus belajar dan disiplin diperbanyak sehingga menjadikan tatanan dunia yang disiplinan dan berilmu.

Bapak Waka kesiswaan Bapak Mashudan S.T juga menambahkan, bukan hanya sarana dan prasarana tetapi antara siswa satu dan yang lainnya kurang dalam menyebarkan virus akan kekaguman kepada tokoh Islam sehingga siswa yang lain belum dapat memahami bahwa tidak ada sebuah negara yang kuat jika melupakan sejarah bangsanya begitu pun juga Islam, Islam tidak akan kuat jika melupakan sejarah dan jasa para aulia Allah SWT dengan mengambil hikmah bahwa para aulia Allah SWT sangat berdisiplin dalam menuntut ilmu.

Dalam faktor penghambat dan pendukung pendidikan agama Islam dalam meningkatkan kedisiplinan siswa kepala sekolah menambahkan. Dalam segala hal pasti ada kekurangan dan kelebihan dan kita perlu belajar bertanggung jawab untuk memenuhi segala kekurangan yang ada dari sarana prasarana dan manajemen penularan kebaikan, harus ada perbaikan selalu yang baik dan komitmen dari saya, 
guru dan siswa itu sendiri (CANDRA ARISTA DEWI, 2019). Memajukan pendidikan di SMA Al- Furqon merupakan tanggung jawab semua warga sekolah sehingga semua elemen harus saling bekerja sama dan saling mengingatkan dalam kebaikan.

\section{Kesimpulan}

Berdasarkan penelitian yang telah dilakukan, dapat ditarik kesimpulan yaitu peran Pendidikan Agama Islam sebagai dasar kedisiplinan siswa di SMA Al-Furqon Driyorejo Gresik dapat di ambil tiga kesimpulan dari tiga topik permasalahan yang ada dalam fokus sebagai berikut.

Pendidikan agama Islam sebagai dasar kedisiplinan siswa di SMA Al-Furqon terletak pada jam aktif KBM maupun tidak aktif KBM. Di samping sebagai ajang pembuktian kecintaan kepada agama, negara maupun almamater sekolah dan yang paling penting pembiasaan PAI sebagai melatih siswa untuk disiplin, bertanggung jawab, mandiri, jujur, kecintaan baik agama, negara, almamater, dan khususnya diri sendiri. Dalam kegiatan tersebut juga dapat memecahkan masalah yang dihadapi siswa untuk lebih menemukan jati diri mereka.

Peran kegiatan pendidikan agama Islam sebagai dasar kedisiplinan siswa SMA Al-Furqon Driyorejo Gresik. Hasil yang dicapai setelah mengikuti kegiatan tersebut yaitu kedisiplinan dan tanggung jawab, sebagai generasi penerus agama dan bangsa. Kedisiplinan siswa adalah harapan bagi sekolah dan tolak ukur dari kegiatan tersebut dan hasil kegiatan tersebut siswa mempunyai disiplin ilmu yang sangat tinggi.

Faktor penghambat dan pendukung kegiatan pendidikan agama Islam sebagai dasar kedisiplinan siswa SMA Al-Furqon Driyorejo Gresik. Adapun faktor pennghambat yaitu kurangnya tersedia sarana dan prasarana, dalam pengelolahan kegiataan kurangnya koordinasi dan kurang adanya kerjasama yang baik dari sekolah, guru dan siswa itu sendiri. Kurang adanya tanggung jawab dan juga siswa kurang responsible dan cenderung monoton sehingga siswa merasa bosan. Adapun membuat faktor pendukung dari kegiatan tersebut adalah adanya sarana prasarana yang memadai, tersedianya manajemen pengelolahan yang bagus dan semangat pada diri siswa tersebut. Adapun adanya faktor penghambat akan disempurnakan dengan adanya faktor pendukung. 
Implementasi Mata Pelajaran Pendidikan Agama Islam Sebagai Dasar Menciptakan Kedisiplinan Siswa Di Smaal-Furqon Driyorejo Gresik

\section{BIBLIOGRAFI}

Ahmad Susanto, M. P. (2018). Bimbingan Dan Konseling Di Sekolah: Konsep, Teori, Dan Aplikasinya. Kencana. Google Scholar

Candra Arista Dewi, D. (2019). Strategi Pendidikan Karakter" Langit Biru" Dalam Meningkatkan Kedisiplinan Siswa Di Smp Negeri 3 Tuban. Inspirasi Manajemen Pendidikan, 7(1). Google Scholar

Ekowanti, M. R. L., \& Casmiwati, D. (2014). Pembangunan Lembaga Dari Konsep Ke Aplikasi (Studi Kasus Lembaga Koperasi Di Wilayah Pesisir Timursurabaya (Pamurbaya). Hang Tuah University Press. Google Scholar

Ghony, M. D., \& Almanshur, F. (2012). Metodologi Penelitian Kualitatif. Jogjakarta: Ar-Ruzz Media, 61. Google Scholar

Maarif, A. S. (2019). Membumikan Islam. Ircisod. Google Scholar

Machrus, S. (2011). Pengaruh Kejiwaan Masa Puber Terhadap Aktivitas Belajar Siswa Di Smp Praja Mukti Surabaya. Uin Sunan Ampel Surabaya. Google Scholar

Mardan, M., \& Halim, W. (2011). Islam Untuk Disiplin Ilmu (Sebuah Pengantar). Google Scholar

Moleong, L. J. (2019). Metodologi Penelitian Kualitatif. Google Scholar

Nasution, S. (2013). Sejarah Peradaban Islam. Yayasan Pusaka Riau. Google Scholar

Pulungan, J. S. (2017). Dinamika Kebudayaan Islam Melayu Di Nusantara. Tamaddun: Jurnal Kebudayaan Dan Sastra Islam, 17(1), 18-36. Google Scholar

Rahmat, M. P. I. (2019). Pembelajaran Pendidikan Agama Islam Berwawasan Multikultural (Vol. 1). Pt Rajagrafindo Persada. Google Scholar

Sam, B. A. Z. (2019). Perlindungan Hak Cipta Terhadap Warisan Budaya Bangsa Indonesia Di Tinjau Dari Perspektif Hukum Internasional. Lex Et Societatis, 7(5). Google Scholar

Setianingsih, D. (2017). Kesinambungan Dan Perubahan Lembaga Pendidikan Di Pondok Pesantren Darul Ulum Jombang. Universitas Airlangga. Google Scholar

Syukri, A. (2015). Peran Religio Politik Sayyid Palembang Di Semenanjung Melayu Pada Abad Ke-18 Dan 19 Masehi. Google Scholar

Winarni, E. W. (2021). Teori Dan Praktik Penelitian Kuantitatif, Kualitatif, Ptk, $R$ \& D. Bumi Aksara. Google Scholar 


\section{Copyright holder :}

Muhammad Refa Mashuri (2021)

First publication right :

Journal Syntax Admiration

This article is licensed under:

(c) $\underset{\mathrm{EV}}{\mathrm{E}} \mathrm{\Theta}$ 